\title{
HEREDITARIEDADE DA HOMEOSE
}

\section{S. de Toledo Piza Junior}

Escola Superior de Agricultura

"Luiz de Queiroz", Universidade

de São Paulo

\section{INDICE}

\begin{tabular}{ll||lcr}
1 - Introdução & 107 & 5 - Desenvolvimento & do \\
2 - Discos imaginais e seu & & 6 mutante aristapédia & 115 \\
\multicolumn{1}{c}{ desenvolvimento } & 108 & - Teoria da homeose & 115 \\
3 - Homeose & 112 & Summary & 117 \\
4 - Homeose hereditária & 113 & Literatura citada & 134 \\
& &
\end{tabular}

\section{1 - INTRODUÇAO}

A homeose, fenômeno, já pela sua natureza, tăo interessante, adquire, sem dúvida, enorme significação biológica, com a descoberta de seu comportamento hereditário. Data de longos anos a constatação de sua transmissibilidade à prole dos individuos em que pela primeira vez foi notada. Entretanto, sòmente com o aparecimento na Drosófila, há alguns anos, póde a homeose receber o tratamento experimental que trouxe para a ciência inúmeros e importantes fatos da mais alta sig- 
Anais da E. S. A. "Luiz de Queiroz»

nificação. Verificada a conduta dos mutantes homeóticos, difícil tornou-se, entretanto, encontrar uma explicação adequada para o modo de açāo dos fatores genéticos a que se atribuiam as modificações operadas nos órgãos afetados. Foi então que GOLDSCHMIDT, ajustando os fatos conhecidos à sua teoria geral das velocidades das reações controladas pelos gens, elaborou uma teoria, que à primeira vista, pareceu esclarecer suficientemente a questão. Contudo, um exame aprofundado daquilo que me pareceu constituir alicerces às concepções teoricas do consagrado autor, logo levou-me à verificação da insegurança das bases em que se acentava a explixcação do fenômeno. Eis porque, há cêrca de 3 anos (1941) submeti a teoria da homeose a detido exame crítico que concluiu pelo seu completo abandono, elaborando, eu, então, nova teoria, assentada em bases inteiramente outras. $\mathbf{E}$ como os mais recentes trabalhos sóbre o assunto têm confirmado os pontos de vista por mim externados contra a explicação de GOLDSCHMIDT, resolvi retomar a questão, estudando o que de mais importante existe no momento a favor de uma melhor compreensão da homeose hereditária, reforçando, ao mesmo tempo, com o resultado experimental do trabalho de diversos autores, os suportes em que se firmam os argumentos por mim anteriormente apresentados.

O presente trabalho se inicia pelo estudo do desenvolvimento normal dos discos imaginais dos insetos holometabólicos, para só então passar a tratar da homeose, de seu comportamento hereditário e das teorias que pretendem explicá-la.

\section{2 - DISCOS IMAGINAIS E SEU DESENVOLVIMENTO}

sabido que em certos insetos, como os Dipteros, por exemplo, as peças bucais, as antenas, os olhos, as patas, as asas e outros órgãos do adulto formam-se à custa do desenvolvimento de estruturas larvais conhecidas pelo nome de discos imaginais (KORSCHELT 1936, DAWYDOFF 1928). Esses discos provêm da hipoderme da larva e se constituem, cada qual a seu tempo, permanecendo alguns na periferia, enquanto outros, conservando-se presos à hipoderme por meio de um tubo bastante delgado, aprofundam-se mais ou menos no organismo, estabelecendo contato com o sistema nervoso e com outros órgăos internos. O tubo que liga o disco à hipoderme da larva não é senão o pescoço de um saco em cujo interior se acha envaginado o disco propriamente dito. (Cavidade peripodal).

No decurso da metamorfose, que se realiza no estado pu- 
pal, os órgãos larvários vão sendo histolisados, enquanto os do adulto se vão progressivamente organizando dos discos imaginais que se desenvolvem. Primeiramente os discos se desenvaginam e aos poucos se vão conformando até que adquirem a estrutura caracteristica dos órgãos a que correspondem. Os discos dos apêndices formados por artículos, como as patas e as antenas, iniciam a segmentação ainda no periodo larval, de maneira que ao desenvaginar-se, no fim do periodo pré-pupal, já se pode néles distinguir um certo número de partes.

No inicio, os discos imaginais năo passam de simples espessamentos da hipoderme, só podendo porisso ser reconhecidos pelo exame de cortes histológicos. Mais tarde, porém, à medida que se vão desenvolvendo, já se vaí tornando possivel encontrá-los pela dissecação da larva. Nota-se, então, uma certa ordem no aparecimento dos discos, de sorte que cada qual só poderá ser encontrado em larvas acima de determinada idade.

$\mathrm{Na}$ Drosophila, que de todos os insetos é o mais interessante para a discussão do problema que temos em vista, os discos imaginais aparecem, segundo CHEN (1929), resumido por STRASBURGER (1935), na seguinte ordem, em larvas mantidas a temperatura de $25^{\circ} \mathrm{C}$ :

1) Os complexos discos óculo-antenais e os discos dorsais medianos, depois de 16 horas, isto é, em larvas de mais de 16 horas de idade;

2) Os discos dorsais posteriores, depois de 24 horas;

3) Os discos podais e dos órgăos copuladores, depois de 32 horas;

4) Os discos labiais, depois de 40 horas;

5) Os discos dorsais anteriores, depois de 56 horas.

interessante constatar que os discos imaginais desde que aparecem no organismo da larva já se encontram determinados, produzindo cada um o órgão do adulto que lhe cabia produzir. Isto quer dizer, que um disco de antena, de olho ou de pata, assim que se deixa reconhecer como tal e pode portanto ser submetido à experimentação, já se apresenta como uma estrutura predestinada a produzir, respectivamente, uma antena, um ôlho ou uma pata do adulto. Essa determinação dos discos, que traduz sua capacidade para produzir os respectivos órgãos é, pois, especifica e se deve, segundo demonstram as experiências de transplantação, a fatọres que resiḍem nọs pró- 
prios discos. E como, sob o pontos de vista de sua constituição histológica, os discos não diferem fundamentalmente entre si, segue-se que o que os distingue quanto à sua capacidade organoformadora, deve ser algum fator de ordem substancial, isto é, qualquer elemento, provàvelmente químico, contido em suas células.

Que o fator determinante dos discos encontra-se nêles próprios, prova-o o fato dos discos transplantados não se deixarem influenciar pela regí̄o do corpo para onde forem levados, produzindo, onde quer que seja, o mesmo orgåo que produziriam caso não houvessem sido removidos de sua posição normal. Que a determinação dos discos se deve a causas intrinsecas, demonstra-se também pelo fato de não haver no organismo que se desenvolve normalmente, em momento algum, qualquer subtância que se difundisse à semelhança de um hormónio e ao atingir os discos fósse capaz de alterar a sua preesta.belecida potenclalidade. As experiências de transplantaçāo de discos de várias idades em larvas em diferentes estádios de desenvolvimento mostram que qualquer que seja a idade dos discos ou das larvas, o disco que conseguir desenvolver-se dará exatamente a estrutura que dêle se esperava.

De acôrdo com os dados de CHEN (1929) acima referidos, os discos podais da Drosophila só depois de 32 horas é que se tornam distintos. Por conseguinte, as larvas que tiverem menos de 32 horas de idade não podem fornecer discos imaginais de patas para a transplantação. Mesmo que o pudessem, seria impraticável a operação em larvas de tão reduzidas dimensões. Entretanto, teria enorme interêsse para a ciência, constatat se os discos imaginais, quando ainda simples espessamentos da hipoderme da larva, já estão definitivamente determinados. Neste estado não é ainda possível operar diretamente com jles. Porém GEIGY (1931), submetendo ovos de Drosophila de diferentes idades à ação dos raios ultra-violetas, conseguiu não só alterar de maneira diversa a estrutura das patas do adulto, como até mesmo suprimí-las. Isso prova, pelo menos, que determinados apéndices do adulto podem ser atingidos, modificados e suprimidos quando o inseto se encontra ainda no estado de ôvo, não passando os discos imaginais nessa ocasião de simples áreas ainda não conformadas do embriáo ou do blastema. Prova, por conseguinte, que tecidos embrionários ou simples células destinados a produzir órgãos imaginais já se achauı determinados no óvo, revelando nas estruturas correspondentes do adulto os efeitos das causas que sôbre êles agiram.

Os olhos e as antenas da Drosophila originam-se cie um 
complexo disco óculo-antenal, cuja parte posterior, ligada ao hemisfério cerebral por melo de delicado pedúnculo, corresponde ao ôlho e cuja parte anterior, mais fina, corresponde à antena. Além disso, o complexo óculo-antenal dá também formação a parte da parede da cabeça. O modo de origem do coinplexo em questão, de um divertículo da parede dorsal da cavidade bucal, e a capacidade formativa especifica de cada uma de suas partes, mostram que uma mesma estrutura larval. histològicamente homogênea, pode achar-se diferenciada em regiōes constitucionalmente distintas, cada qual se incumbindo, de conformidade com a sua própria constituição, da forraçăo de um determinado órgāo do adulto. E como na mesma estrutura existem regiōes destinadas à produção de órgãos diferentes, segue-se que a capacidade órgano-formativa de cada narte está determinada nas células que a constituem e não depende, especlficamente, de nenhuma influência extrínseca que lhe pudesse chegar através de humores circulantes, à guiza de hormónios, que então atingiriam e modificariam ao mesnıo tempo tôdas as partes da estrutura. Em outras palavras, se a região anterior do complexo oculo-antenal sempre se desenvolve em antena e a posterior em ólho, é porque estas regiōes, apesar-de pertencerem a um mesmo todo morfológico, possuen: uma potencialidade organogênica individual e distinta, que se não deixa influenciar pela região vizinha de que é direta continuação. Quer dizer, que cada parte do complexo só produzirá aquilo para que se acha prèviamente destinada em consequência de um determinismo biológico que reside nas células que a constituem. Para onde quer que cada parte seja experimentalmente transportada, se as condições do novo meio permitirem o desenvolvimento, ela af dará a estrutura que dela se esperava. Provam-no as inúmeras experiências de transplantação realizadas, com os mais variados fins, por diversos pesquisadores.

BODENSTEIN (1941), dividindo longitudinalmente ao meio discos podais de Drosophila e implantando separadamente os fragmentos no abdome de larvas da mesma idade, póde verificar que nas estruturas oriundas de uma das metades formavam-se as garras tarsais, enquanto que nas provenientes da outra metade não havia traço algum de tais órgãos. Combinando êsses resultados com os obtidos pela implantaçăo de fragmentos provenientes da divisão dos discos por um plano transversal, pôde aquêle autor localizar na parte central do disco uma pequena área responsável pela formação das garras. 
E por se encontrar essa área exatamente no centro, ela ficará de um lado ou de outro do plano longitudinal, passando só para um dos fragmentos resultantes, ou, sendo atingida pelo instrumento utilizado na prática da secção, poderá ser destruida, ficando neste caso ambas as partes destituidas da área formadora de garras. Assim explica BODENSTEIN a ausência de garras em alguns casos em que essas estruturas eram esperadas.

Os resultados de BODENSTEIN demonstram que também nos discos imaginais destinados a formar as patas do adulto existe uma diferenciação regional e que as garras só se desenvolvem à custa de uma determinada área dos discos. Só os fragmentos que contiverem essa área produzirão garras. Os dela destituidos serão incapazes de regenerá-la e por conseguinte não poderão dar origem àquelas armas tarsais.

Não sabemos ainda quantas áreas potencialmente distintas existem num disco imaginal. Se todos os segmentos de uma pata transplantada no estado de disco imaginal para o abdome de uma larva fôssem bem caracterizados como o último artículo tarsal pelas garras que possui e o primeiro do tarso do macho pela presença do "pente sexual", talvez viéssemos a descobrir serem os discos verdadeiros mosáicos de áreas de valor formativo diferente, correspondendo às diversas partes da pata do adulto (fêmur, tíbia, tarso), as quais poderiam por seu turno subdividir-se em áreas mais limitadas destinadas à formação de garras, esporas, pentes e outras estruturas menores.

\section{3 - HOMEOSE}

E o fenômeno caracterizado pelo aparecimento no adulto de certos órgãos em lugar daqueles que deveriam formar-se no desenvolvimento normal do ser. Nos Artrópodes os casos mais conhecidos referem-se à substituição de uma pata por uma outra pertencente a um par diferente, de uma antena por uma pata, de um ollho por uma antena, de uma asa por outra, etc. (YORSCHELT 1927, PRZIBRAM 1909, BATESON 1894).

A substituição experimental de antenas por patas em Fásmidas levada a efeito por CUENOT (1921) e outros investigadores, o desenvolvimento de antenas em lugar dos olhos provocado pela extirpaçáo do pedúnculo ocular em Crustáceos Decápodes (HERBST 1896) e vários outros casos da mesma natureza, ligam estreitamente a homeose aos fenómenos de regeneração.

Conforme as circunstâncias, o órgão extirpado, ao regenerar-se, reproduz o mesmo órgăo ou se desenvolve em um órgão 
inteiramente diferente. No primeiro caso fala-se simplesmente em regeneração; no segundo, em homeose. Esta última só difere da primeira pela forma do órgão envolvido no fenômeno. Ambas, porém, traduzem um mesmo processo de nova formação de orgãos em substituição àqueles que foram suprimidos do organismo. Sem essa faculdade que o organismo traz em potencialidade, de reconstruir partes que já se haviam constituido no decurso de um desenvolvimento normal, à custa de reservas latentes, a homeose não seria possivel e nem tão pouco a regeneração. Mas há casos observados principalmente nos Insetos, nos quais o órgão diferente não aparece em substituição a outro prèviamente formado e sim surge como uma estrutura de primeira formação. Estes são verdadeiros êrros da natureza, devidos aos quais, um esbóço do qual se esperava o desenvolvimento de uma antena ou de uma asa, produz diretamente uma pata ou um haltere. Nesse grupo se incluem os casos de homeose hereditária, que passaremos a estudar.

\section{4 - HOMEOSE HEREDITARIA}

Inúmeros autores têm feito referências à homeose hereditária observada na natureza em diversas ordens de Insetos. Porém, que me conste, sòmente na Drosophila tem êsse fenómeno sido suficientemente estudado, razăo pela qual deixarei de mencionar os outros casos.

Na Drosophila, segundo o resumo de VILLEE (1942), são os seguintes os exemplos conhecidos:

a) Bitórax - Descrito por BRIDGES e MORGAN em 1923. O metatórax assemelha-se ora mais ora menos ao mesotórax. Os halteres variam de aspecto, apresentando-se às vezes achatados e providos de nervuras como as asas. As patas metatorácicas algumas vezes apresentam uma cerda no ápice das tíbias, característica das patas mesotorácicas. Conhecem-se dessa mutação diversos alelos que variam quanto à intensidade de sua manifestação, alguns dos quais se aproximam bastante do tipo normal.

b) Bitoraxóide - Descrito por BRIDGES e MORGAN na mesma ocasião, assemelha-se ao precedente sobretudo pela forma dos halteres.

c) Tetráptera - Descrito por AUSTAROFF em 1927 e 1929, êsse mutante torna-se notável pelo seu alto grau de variabilidade, sendo que muitos indivíduos em nada se distinguem da 
forma normal. Em oposição aos tipos aparentemente normais, outros existem cujos halteres se desenvolvem exatamente como as asas metatorácicas. Uma série de formas intermediárias liga os tipos extremos.

d) Aristapédia - Descrita por BALKASHINA em 1929, essa mutação afeta a arista das antenas, que se transforma em tarso. interessante notar que muitas vezes as antenas apenas se reduzem a dois segmentos, apresentando-se inteiramente destituidas de aristas, enquanto que nos casos extremos, além dos três segmentos antenais, os cinco artículos dos tarsos também se desenvolvem. O fenótipo desta mutação é bastante variável. Aristapédia-Bridges e aristapédia-Spencer, são alelos dessa mutação.

e) Proboscipédia - Trata-se de uma mutação descoberta por BRIDGES e DOBZHANSKY em 1933, que afeta a armadura bucal da Drosophila e principalmente a probóscide, cujos lobos são substituidos por um par de apêndices ora parecendo antenas, ora tarsos. O fenótipo das moscas exibindo essa mutação é igualmente muito variável.

f) Oculipalpi - a denominação que proponho para uma mutação que substitui os olhos por uma espécie de palpo ou de antena, ou se desenvolve numa estrutura mista em que o apéndice articulado se acha associado a um ólho mais ou menos rudimentar. (GOLDSCHMIDT 1940). Aqui, igualmente, o fenômeno se mostra variável.

g) Tetráltera - Segundo GOLDSCHMIDT (1940), neste mutante as asas anteriores são substituidas por halteres, havendo uma série progressiva de formas que conduzem aos individuos providos de 4 halteres.

VILLEE (1942) aponta as seguintes importantes particularidades comuns a êsses mutantes, pelas quais êles se afastam dos outros.

a) Os fenótipos são muito variáveis, formando uma série que vai do normal até a completa substituição de um órgão por outro.

b) Nota-se grande variaçāo na percentagem dos indivíduos homozigotes para a mutação que exibem o caráter. (Penetração).

c) O grau de simetria com que se apresenta o caráter varia grandemente, sendo raros os individuos perfeitamente simétricos. 
d) Há um baixo grau de correlação lateral na expressão do caráter.

\section{5 - DESENVOLVIMENTO DO MUTANTE ARISTAPEDIA}

Além da tetráltera (VILLEE 1942a), apenas o mutante aristapédia (BALKASHINA 1929) foi estudado quanto ao desenvolvimento embrionário. E visto que GOLDSCHMIDT (1938-1940) baseou-se nos dados de BALKASHINA para desenvolver a teoria da homeose por mim criticada (PIZA 1941) e depois também por VILLEE $(1943,1944)$, farei aqui apenas um resumo do que se sabe relativamente a aristapédia.

De acôrdo com BALKASHINA o disco antenal do mutante aristapédia inicia a segmentação cêrca de $21 / 2$ dias mais cedo que na Drosophila normal. Enquanto que nesta última a segmentação só começa nas larvas de $41 / 2$ dias de idade, no mutante em questão tem início já nas larvas de 2 dias. Esta antecipação faz coincidir o desenvolvimento dos discos antenais com o dos discos podais que a seguir se inicia. $\mathrm{Na}$ época em que deveria começar a segmentação dos discos antenais na larva normal, isto é, aos $41 / 2$ dias de idade, quando esta se encontra em vias de pupar, na larva mutante aquéles discos já exibem 5 dos seus 7 ou 8 segmentos. E 3 horas após a entrada da larva no estado de pupa, quando a antena normal exibe os seus 3 segmentos definitivos, o disco mutante completa também o seu desenvolvimento. Daqui por diante, ao passo que a antena normal se conforma e diferencia no terceiro segmento a sua típica arista, no mutante aquêle órgão de 7 ou 8 segmentos evolui na direção do tarso, dando origem a característico revestimento de pêlos e cerdas, bem como produzindo pulvilos e garras.

\section{6 - TEORIA DA HOMEOSE}

GOLDSCHMIDT (1938, 1940) procura explicar a ação do gen aristapédia estendendo sôbre o fenômeno a sua teoria geral da velocidade das reações controladas pelos gens. (1927). Conforme já tive oportunidade de referir (PIZA 1941), é a seguinte a explicação de GOLDSCHMIDT:

No desenvolvimento normal os processos genéticos realizam-se numa ordem definida, controlada, de conformidade com a sua teoria geral, pela produção de substancias determinadoras, com uma velocidade por seu tur. 
no definida, que conduz, dentro de determinado tempo, à condição requerida. Um processo como êsse determina a segmentação dos discos imaginais em desenvolvimento. Iniciando-se a indução, todos os discos que se encontrarem em condições, serão estimulados a segmentar-se. A marcha normal relativa do desenvolvimento e da determinação nos discos é tal, que cada um se encontra preparado para receber a indução num momento definido. Quer dizer, existe para cada disco um momento do desenvolvimento que coincide com o momento da indução. Em outras palavras, cada disco recebe o necessário estimulo quando tiver atingido um certo grau de maturidade. Uma mutação que abrevie o tempo da determinaçăo dos discos antenais, fazendo-o coincidir com o tempo da determinação dos discos de patas, produz automáticamente uma pata em lugar de uma antena. O agente (o gen), por conseguinte, acelerando o desenvolvimento dos discos de antenas, fá-los entrar em maturidade conjuntamente com os discos de patas e o evocador, que no momento preciso "ordena" a formação dos tarsos, alcança também os discos antenais, obrigando-os a se desenvolver da mesma maneira.

Em resumo, a teoria de GOLDSCHMIDT é a seguinte:

Os discos imaginais se encontram todos em estado indiferente no momento de receber a ação genética que deve determiná-los. Essa ação atinge os discos respectivos num momento preciso, exatamente quando êles se encontram em perfeitas condições de receber a influência de origem gênica. Em qualquer outro momento a atuação do gen seria ineficaz. Nos indivíduos normais, quando os discos de patas atingem a maturidade, isto é, quando êles alcançam aquêle estado de desenvolvimento capaz de ser influenciado, sofrem a ação catalítica dos gens que devem determiná-los, iniciando-se desde logo a formação das patas. Os discos de antenas, que nessa ocasião não se encontram ainda maduros, não experimentam influência alguma e por isso não se diferenciam. Quando êstes, por sua vez, atingem a maturidade (momento efetivo), recebem, por seu turno, a intervenção genética que orienta o desenvolvimento para o lado das antenas. Uma mutação que faça com que os discos antenais, amadurecendo mais ràpidamente, atinjam o momento efetivo junta- 
mente com os discos de patas, faz com que êles, sofrendo a ação dos principios elaborados pelos gens operantes na ocasião (gens de patas), recebam idêntica determinação e consequentemente se desenvolvam em patas..

\section{7 - DISCUSSÃO}

BALKASHINA havia já concluido de seus estudos, que o efeito do gen aristapédia seria de estimular os discos antenais mais cedo que ordinariamente, fazendo-os entrar em segmentação ao mesmo tempo que os discos podais, orientando o seu desenvolvimento para o lado dos tarsos.

A primeira parte das conclusões dessa autora é aceitável à luz dos seus resultados experimentais, porquanto ficou demonstrado que os discos antenais do mutante aristapédia segmentam-se de fato mais cedo que os das larvas normais, coincidindo o seu desenvolvimento com o desenvolvimento dos discos podais. Essa antecipação pode perfeitamente ser atribuida a um efeito gênico. Entretanto, parece-me que a segunda parte, ou seja, a orientaçāo do desenvolvimento dos discos antenais no sentido de produzirem tarsos, não só deixa de ter qualquer relação com a causa aceleradora que atua sôbre os discos, como também. não pode ser compreendida como o simples resultado de uma ação gênica, no sentido de GOLDSCHMIDT. Ora, se um disco antenal se desenvolve em tarso em consequência d€ ter sido levado a segmentar-se ao mesmo tempo que os discos podais, a transplantação de um disco maduro de antena de uma larva normal para o organismo de uma larva aristapédia exatamente no momento em que os discos de patas estão iniciando o seu desenvolvimento, deveria dar como resultado tarso e não antena. Entretanto, não é isso o que se verifica. BRAUN (1940), transplantando discos antenais de larvas normais em larvas aristapédia cuja idade variava de $21 / 2$ dias até o estado de pupa, constatou que a estrutura produzida era antena e não tarso. A transplantação, nas mesmas condições, dos discos antenaìs de aristapédia em larvas normais, por seu turno, sempre produziu tarso. Esse último resultado sugeriu a BRAUN a possibilidade dos discos antenais diferenciarem-se antes da época da transplantação, isto é, em larvas de menos de 2 1/2 dias de idade. O fato dos discos antenais normais desenvolverem antenas nas larvas aristapédia năo permite, de acôrdo com aquêle autor, nenhuma conclusão quanto ao tempo da determinação da aĩtena. Entretanto, é possivel, na sua opinião, que os discos se- 
jam determinados muito prematuramente, de maneira que a transplantação não pode revelar a sua potencialidade. A conclusão final do autor, segundo a qual, o fator aristapédia, acelerando o desenvolvimento dos discos antenais, antecipa o inicio da diferenciação dêsses discos, de maneira que nas larvas de 2 1/2 dias de idade já se encontrem suficientemente maduros para responder ao "evocador de patas" e iniciar a segmentação como tarsos, é exatamente a conclusão de BALKASHINA, enquadrada na teoria de GOLDSCHMIDT. Contudo, na minha opinião, os resultados experimentais de BRAUN, servem, de modo algum, de suporte à explicação proposta por GOLDSCHMIDT. A única cousa que as suas experiências verdadeiramente provam é que no momento da transplantação os discos antenais de aristapédia já se achavam determinados no sentidc de produzirem patas e que êsses mesmos discos da larva normal estavam por sua vez determinados como antenas. Não se pode concluir dos resultados de BRAUN que os discos antenais de aristapédia sejam na verdade discos indiferentes no sentido de GOLDSCHMIDT, que atingindo a maturidade so tempo em que o "evocar de patas" entra em ação, determinamse como patas e como patas se desenvolvem. Não, os discos antenais de aristapédia, pròpriamente falando-se, não são discos antenais e sim discos podais que se constituiram em lugar daqueles e como tais se desenvolvem conjuntamente com os demais discos de patas. A determinação dos discos é intrínseca e independe de "evocadores" vindos de fora.

Uma consequência interessante das experiências de BRAUN e francamente contrária à hipótese dos "evocadores" provém do fato dêsse autor haver efetuado transplantações de discos antenais em larvas que iam de $21 / 2$ dias de idade até ao estado de pupa. E como um disco antenal de aristapédia se desenvolve em tarso qualquer que seja o momento daquele longo período, segue-se que se a determinação do disco for devida à ação de um "evocador", êsse evocador, uma vez produzido, permanece em atividade por largo tempo, devendo atingir igualmente outros discos imaginais que forem entrando em maturidade. O mesmo se deve esperar de qualquer outro evocador. $E$ assim, os discos que fôssem sucessivamente amadurecendo, scfreriam a ação conjunta de diversos evocadores, tornando-se dificil compreender, como possam êles, apesar disso, produzir, nas condições normais, exatamente aquilo que se esperava. provável que os discos dos três pares de patas amadureçam ao mesmo tempo e sofram ao mesmo tempo a ação dos evocadores que devem guiá-los à produção de patas respectivamente 
pro, meso e metatorácicas. Apesar désses três evocadores especificamente diferentes se difundirem no organismo e alcançarem ao mesmo tempo todos os discos podais, cada qual só produz uma pata segundo a estrutura esperada. Isso significa que a determinação se processa no próprio disco e não depende de evocadores. Estes, se existirem, devem atuar conjuntamente, sem qualquer especificidade, para provocar o desenvolvimento de estruturas prèviamente determinadas por algum outro processo. Aliás, as dificuldades mais importantes da teoria de GOLDSCHMIDT foram já por mim criticadas da seguinte maneira:

A teoria geral das velocidades das reações proposta por GOLDSCHMIDT obriga-nos a assumir que o desenvolvimento das diversas partes do embrião e a produção pelos gens das substâncias de ação catalítica que devem determiná-las, são dois processos convergentes, porém, completamente independentes. As regiōes indiferentes do embriāo não podem provocar a elaboração por parte dos cromossômios dos produtos específicos que efetuam a sua determinação, exatamente por serem indiferentes e porque, no caso contrário, um disco de patas, atingindo a maturidade, provocaria a elaboração da substáncia determinante de patas e um disco de antenas, nas mesmas condições, provocaria a elaboração da substância especifica que o transformaria em antena. E dêsse modo, mesmo que os discos antenais, em virtude de uma mutação, alcançassem a maturidade mais cedo e isso coincidisse com a entrada em maturidade dos discos de patas, cada qualidade de discos, provocando a elaboração do catalisador especifico, se desenvolveria, os de patas em patas e os de antenas em antenas.

Não sendo provocada a produção da substância diferenciadora pela entrada do tecido indiferente em maturidade, segue-se que essa substância deve ser elaborada antecipadamente para que possa, no momento efetivo do desenvolvimento dos órgãos embrionários, encontrar-se também em quantidade efetiva. Se a produção da substância coincidir com a entrada do tecido em maturidade, éste pode ser atingido antes pelo produto que já operou em situação prévia e que ainda se encontra no organismo.

As substâncias determinadoras aparecem numa determinada sequência. Nos indivíduos normais primeiramente são produzidas as que determinam patas e depols as que 
determinam antenas. Se fôssem produzidas ao mesmo tempo, haveria um conflito por ocasião da determinação dos tecidos ou órgãos que alcançassem sucessivamente a maturidade. Mas, mesmo assim, é necessário que o catalisador que já entrou em função desapareça do organismo ou seja neutralizado pelos que se formarem depois, sem o que o conflito se dará no momento em que outro tecido ou órgão entre em maturidade. Por ocasião da determinação das antenas não deve mais existir o catalisador de patas ou a atuação dêste deve ser inibida pela atuação daquele. Entretanto, não há razão para o desaparecimento de uma substáncia de ação catalitica produzida espontâneamente sem um estímulo de caráter específico. Se o catalisador fôsse elaborado em resposta a um apélo direto do tecido sôbre o qual deveria atuar, então se compreenderia que a sua produção se desse em quantidade estritamente necessária e proporcional à intensidade do apêlo e, cessando êste, cessaria concomitantemente a produção. De outro lado, imaginar que cada catalisador que aparece exerce uma ação inibidora sôbre todos os outros, exigiria que se atribuisse a êsse catalisador a faculdade de determinar, num simples e momentâneo contato, tôda uma complexa arquitetura.

A teoria de GOLDSCHMIDT exige que cada célula, tecido ou órgão seja determinado a seu tempo, porque do contrário, a presença de catalisadores ativos operando ao mesmo tempo, traria certamente graves distúrbios. Assim, por exemplo, se todos os discos imaginais fóssem determinados concomitantemente, o catalisador de qualquer dos esbóços embrionários dos discos poderia atuar indiferentemente sôbre qualquer dos outros e de um disco de ôlho poderia nascer uma asa ou uma pata ou do disco de pata poderia desenvolver-se uma antena ou um ólho.

O desenvolvimento simultâneo de diversos apêndices, se bem que mais lentamente aqui, mais ràpidamente alf, fala em favor de uma determinação por sua vez simultânea.

Os discos imaginais das asas anteriores e posteriores de vários Insetos originam-se ao mesmo tempo como simples espessamentos dorsais da hepiderme do meso e do metatórax. Entretanto, podemos aceitar que os discos de um dêsses segmentos tenha recebido a determinação um pouco mais cedo que os do outro. Mas, como o desenvolvimento dos esbôços discais prossegue paralelamente, bem 
como o desenvolvimento das asas, conclui-se que o lapso de tempo decorrido entre as duas determinações deve ter sido bastante curto. E para que o agente determinante que operou anteriormente não exerça nenhuma influência na determinação dos segundos esbóços, é preciso que êle desapareça ou seja inibido pelo agente que opera a determinação dêstes últimos. $\mathbf{E}$ visto que o aparecimento do segundo determinante se faz logo depois que o primeiro iniciou o seu trabalho, torna-se necessário que o primeiro opere uma determinação quase que instantânea dos discos respectivos, para deixar o campo livre à atuaçāo do segundo. Quer-me, porém, parecer, que a determinação não pode resultar de um passageiro contato do agente ativo com o tecido indiferente. Durante todo o tempo relativamente longo que leva o desenvolvimento, até que cada esbôço adquira uma conformação tal que não possa mais ser virada para outra direção, o agente determinnador deve permanecer em atividade, porque senão o esbóço ainda não conformado poderia ser torcido pelo outro agente para um rumo inteiramente diverso.

A teoria de GOLDSCHMIDT apresenta-nos o organismo como uma série de complexos cronómetros (tantos pares quantas sejam as determinações a fazer) e regulados de tal sorte que quando um cronômetro que marca a velocidade do desenvolvimento do esbôço embrionário coincide com o que regula o tempo efetivo de entrada em açāo do catalisador que se destina a determiná-1o, nenhum outro par deve entrar ao mesmo tempo em coincidência. A teoria é, pois, de um mecanismo tão rigoroso, que se torna incompativel com a maneira de se processarem os fenômenos biológicos. Inúmeras são as causas que aceleram ou retardam a marcha normal dos processos ou reaçōes que se desenrolam no organismo. E uma vez que a teoria não nos oferece um mecanismo de auto-regulação que permitisse um reajustamento de todos os cronómetros quando qualquer dêles aumentasse ou diminuisse a sua velocidade, ela não se encontra em condições de explicar porque, apesar-das influências que alteram a cada passo o ritmo do desenvolvimento, êste se conclui geralmente de uma maneira normal.

A teoria da velocidade das reações fala na difusão pelo organismo em formação da substância que produz a determinação. (GOLDSCHMIDT 1938, pag. 209). assim que o catalisador de patas pode atingir os discos antenais, 
quando a maturidade dêstes coincidir com a dos discos podais. A teoria livrar-se-ia de algumas sérias dificuldades se admitisse que a substáncia de origem genica destinada a determinar num momento preciso o esbóço embrionário que alcançasse a maturidade, fôsse produzida sómente pelos cromossômios das células do respectivo esbóço. ficando a sua influência limitada a êsse esbóço. Mas nêsse caso precisaríamos buscar uma outra explicação para a homeose. Para dar conta da transformaçăo das antenas em patas poderíamos supor que a mutação, ao envés de acelerar o desenvolvimento dos discos antenais, teria, simplesmente, feito com que os catalisadores de patas, que normalmente não devem ser produzidos nos discos de antenas, fóssem af elaborados no momento em que costumam aparecer nos discos podais e que os catalisadores de atenas não mais fôssem nêles produzidos.

A questão do momento da determinação de um tecido indiferente é uma das mais complexas da embriologia experimental. No que se refere aos Insetos holometabólicos, tudo leva a crer que os discos imaginais estejam determinados desde muito cedo, talvez mesmo quando ainda simples áreas prospetivas do blastema. Duma cousa, porém, estamos certos. que, no momento em que êles iniciam o seu desenvolvimento para se transformarem nos respetivos órgãos imagiais, já se encontram perfeitamente determinados. As experiências de transplantação de discos de várias idades revela que desde que êles estejam em condições de poderem ser removidos, já se apresentam determinados, cada qual só produzindo o orgão que deveria produzir em situaçס̃es normais, a despeito da regiāo em que forem implantados e dos órgãos sôbre que vierem a aderir. O que se verifica na Drosophila a respeito do desenvolvimeento antecipado dos discos de patas relativamente aos de antenas, nada tem que ver com a determinação dêsses discos. Todos êles já se encontram determinados por ocasião da metamorfose, embora uns possam se desenvolver mais ràpidamente do que outros ou iniciar a segmentação um pouco mais cedo ou mais tarde. Uma mutação que viesse acelerar o desenvolvimento dos discos antenais poderia apenas fazer com que as antenas e as patas se completassem ao mesmo tempo, mas seria incapaz de converter antenas em patas.

A explicação de GOLDSCHMIDT toma por base uma assunção que não podemos aceitar, qual seja a da indeter- 
minação dos discos imaginais por ocasião de sua entrada em segmentação.

BRAUN (1940), submetendo a teoria de GOLDSCHMIDT a testes experimentais, efetuou também uma série de cruzamentos entre moscas aristapédia e moscas portadoras de gens que modificam as antenas e os tarsos. Se a explicação de GOLDSCHMIDT for correta - diz BRAUN - uma combinação de aristapédia com diferentes mutantes que atuam sóbre as patas deve mostrar o seu efeito nas antenas de aristapédia, bem como nas patas, enquanto que as combinações com mutantes que afetam as antenas não devem produzir efeito algum.

Para o primeiro caso foram escolhidas duas mutaçóes recessivas localizadas no II cromossômio, "dachs" e "thickoid", ambas reduzindo enormemente o comprimento das patas.

Os resultados dessas experiências provaram, que tanto num cruzamento como no outro, o efeito dos gens ensaiados manifestou-se claramente nas antenas de aristapédia.

BRAUN vê nisso confirmação da explicação de GOLDSCHMIDT. Entretanto, a meu ver, o grande interêsse de suas observaçóes está no fato delas provarem que os discos antenaís de aristapédia são, na verdade, discos podais.

Para o segundo caso foi escolhido o mutante "aristaless", igualmente recessivo e localizado no II cromossómio, cujo efelto se manifesta por uma redução da arista e por tornar eretas e divergentes as cerdas escutelares posteriores.

Aqui o fator introduzido se fez sentir sôbre as cerdas do escutelo, mas não teve atuação alguma no sentido de modificar a antena. que a antena de aristapédia, assim chamada somente em virtude da posição que ocupa, sendo na verdade pata, não deveria deixar-se influênciar, como de fato se deu, pelos agentes modificadores de antenas. O efeito sóbre as cerdas escutelares posteriores mostrou tratar-se de um gen ativo que provàvelmente modificaria da maneira esperada as antenas de aristapédia se estas fôssem realmente antenas, isto é, se se tivessem desenvolvido de discos imaginais determinados como antenas.

WADDINGTON (1940), referindo-se a trabalhos anteriores, dá conta dos resultados obtidos do estudo de mais dois alelos de aristapédia, ou sejam, aristapédia-Bridges e aristapédiaSpencer, e de suas combinações.

Aristapédia-spencer é, de todos, o mais vigoroso, produzindo, no lugar da arista, uma estrutura inteiramente semelhante a pata. Aristapédia-Bridges é o mais fraco, não conseguín- 
do modificar senão parte da arista, que apenas na base apresenta uma estrutura tarsal. Este último mutante, portanto, exibe, em lugar das antenas, um reduzido tarso terminado distalmente por uma arista.

Segundo WADDINGTON, nas combinações de aristapédiaSpencer com aristapédia-Bridges, os gens se comportam como se êles diferissem quantitativamente, produzindo formas intermediárias entre as duas homozigotes de que se originaram. Seria - escreve aquêle autor - como se diferentes regióes da arista requeressem diferentes concentraçóes de uma dada substáncia para transformá-las em tarsos e cada alelomorfo produzisse uma quantidade definida daquela substância. Ou então, poder-se-ia supor que a variação no efeito fôsse devida à variaçăo no tempo que leva a "substância produtora de tarso" para alcançar uma concentração efetiva, o que, em aristapédia-Bridges se dá tão tardiamente, que parte do disco antenal, já se encontrando determinada, não mais poderá ser atingida.

WADDINGTON afirma que não se trata em aristapédiaBridges de uma estrutura intermediária entre tarso e arista e sim de um orgão composto de tarso na sua porção proximal e de arista na sua porção distal. Para ésse autor, o caminho seguido por um disco imaginal que se desenvolve, num dado momento bifurca-se, devendo o disco seguir uma das vias que conduzem à diferenciaçăo: ou toma a via antenal e dá origem à arista ou segue a via tarsal e se diferencia em tarso, o que deve realizar-se muito prematuramente.

Parece evidente que no caso de arisiapédia-Bridges, um esbôço embrionário indiferente, depois de ter tomado uma das vias, a podal, e começado a se diferenciar em tarso, encaminha-se de súbito pela outra via e completa o seu desenvolvimento como arista. Não podemos compreender que um esbóço orgánico depois de ter sido compelido a tomar um dos caminhos em que se bifurca a trajetória do desenvolvimento, se enveredasse pelo outro, sem voltar ao ponto de bifurcação. Mas, voltar ao ponto de bifurcação significa regressar ao estado embrionário indiferente, o qe evidentemente não se dá, visto que a parte já determinada continua a se desenvolver segundo a primitiva determinação. O que de fato se conclui é que a via seguida pelo desenvolvimento, mais de uma vez se bifurca. $O$ esbóço indiferente, desde que toma o rumo do tarso, assinala a primeira bifurcação. Depois de se desenvolver nesse sentido, tomando o caminho da antena e se completando como arista, assinala a segunda bifurcação. $O$ ponto em que 
se processa esta segunda bifurcaçăo varia, dando como resultado tôda uma série de fenótipos diferentes que se caracteriz:am pela maior ou menor proporção da parte tarsal em relacão á parte aristal. Isso nos leva a supor que as diferentes partes que constituem o órgão recebem, quando no estado de esbóço embrionário, determinação individual e independente, de sorte que no mesmo disco uma regiăo se determina como tarso, começando desde logo a se diferenciar nesse sentido, ao passo que outra continua indiferente, só mais tarde recebendo a determinação do agente formador de arista. Parece-me, que a única maneira de compreender como possa um disco imaginal em desenvolvimento deixar-se determinar apenas parcialmente como tarso, para mais tarde, receber na parte mantida em estado indiferente, determinação como arista, é aceitando a. interpretação de VILIEE (1942), segundo a qual nem tôdas as partes do disco amadurecem ao mesmo tempo. Procurando interpretar o fenômeno à luz da teoria de GOLDSCHMIDT, VILLEE assume que apenas parte do disco antenal sofre a ação aceleradora que o faz atingir a maturidade ao mesmo tempo que os discos podais e por ésse motivo, recebendo a influêncla da substancia determinante de pata, como tal se desenvolve, ao passo que o resto, continuando a se desenvolver com a velocidade normal, só chega à maturidade num momento também normal, que coincide com a entrada do evocacor de antena em atividade, determinando-se como arista e como arista se desenvolvendo.

O sistema do "Branching track" de WADDINGTON em nada de essencial difere da teoria de GOLDSCHMIDT. Como esta, aquêle sistema igualmente só funciona sob a hipótese da existência de discos indiferentes que recebem a determinação no momento de se decidirem por uma ou por outra das vias em que se divide o rumo do desenvolvimento. Como. a teoria das velocidades das reaçóes de GOLDSCHMIDT, o sistema dos caminhos ramificados de WADDINGTON considera a determinação do esbóço primitivo como sendo devida a substáncias elaboradas pelos gens, embora essas substâncias, na opiniáo de WADDINGTON e de conformidade com os resultados de BRAUN, não possam difundir-se pelo organismo. Seria então para aceitar a sugestão de PIZA (1941) acima referida, segundo a qual, a substáncia especifica destinada a determinar os ciiscos, fósse produzida nos próprios discos. Assim, um disco de patas, à medida que fosse se desenvolvendo, iria elaborando uma substância ativa, que, alcançando a concentraçăo efetiva no momento em que êle completasse a sua maturidade, deter- 
miná-10-ia definitivamente como pata, o mesmo se dando com os demais discos. Aliás, VILEE (1944)', pór 'seu turno, acabou concluindo, que, os evocadores, no séntido de GOLDSCHMIDT, não precisam, ser substâncias difusivèis produzidas alhures e que atingissem, os discos imaginaị à śemelhança de certos hormónios que se conhecem dos Insetös. Pođẹm ser substâncias de tamanho molecular grande demais pära $s e^{-}$difundirem através da membrana celulàr, produzidä em cadà célula. Podem originar-se do núcleo das células de cada disco e passar para o citoplasma por ocasiăo da desintégráçảo da membrana nuclear na mitose. Entretanto, êsse pónto de vista, conforme salientou . PIZA, implica em radical modificação na teoria de GOLDSCHMIDT, porquanto, desde que se aceite a produçăo de evocadores especificos em cada dísco, nenhum esbôço discal poderia mais receber de qualquer outro ä influência determinadora e.um disco antenal que amadurecesse mais cedo que de ordinário e fósse porisso levadó a desenvolver-se conjuntamente com os díscos podais, em hipótese alguma poderia dar origem a patas. A homeose poderia entåo sèr compreendida se admitíssemos cue o gen responsável ao envés de acelerar a maturação đo diśco antenal, provocasise nelé a produção de substâncias determinadoras de patas, èm 'substituição aos evocadores de antenas aí normalmente produzidos.

WADDINGTON (1940), à semelhänça de BRAUN (1940), procurou estudar o contrôle gênicó do desenvolvimento de aristapédia, pela introdução naquelé mutante, de fatores genéticos influindo sôbre os tarsos e as antenas.

Usando gens que encurtam o tarso pela redução de seus artículos ("dachs", também usado por BRAUN, "four-jointed" e "approximated"), constatou aquêle autor que os mesmos efeitos. se podem notar quando o órgão de àristapédia se desenvolve na direçăo dos tarsos. De outro läo, empregando "thread", que modifica a arista, suprimindo os seus ramos laterais, verificou igual efeito sôbre a parte aristal do orgão.

Esțes résutlados são perfeitamente semelhantes aos já referidos de ḅRAUN, e como aquếles, provam que os gens, funcionando como uma pedra de tọque, revelam a verdadeira natureza dos discos imaginais. As partes que sofrem a influência dos gens de antenas provêm indubitàvelmente de discos antenais, ao passo que as que se deixam modificar pelos gens de patas, provếm do desenvolvimentó de discos podais. Os órgãos mistos, pela mesma razão, devem se originar de discos por sua vez mistos.

Segundo WADDINGTON" (1940), o gen dominante "eye- 
less" (supressor dos olhos), que frequentemente duplica as antenas da Drosophila, atua da mesma maneira em aristapédia. Este fato é apresentado pelo autor com o intúito de mostrar que contràriamente ao que se dá com os gens que só modificam a parte tarsal ou a parte aristal do orgão, outros gens existem, cuja ação se faz sentir antes da bịurcação da linha do desenvolvimento. Entretnto, sob um outro ponto de vista, êste exemplo de WADDINGTON tem importạnte significação. E que êle nos revela a possibilidade de substịtuição completa de um esbôço embrionário por outro de órgãa diferente. No caso तe "eyeless" ou de sua combinação com aristạpédia, a duplica ção das antenas e a ausência dos olhos podẹm șer interpretadas como se a antena suplementar ou o orgåo que lhe corresponde proviesse de um primitivo complexo. Imaginal cuja parte ocular fôsse igualmente determinada como, a parte antenal.

VILLEE (1943) realizou interessantes experiências sôbre os efeitos da temperatura na expressão dos caracteres de aristapédia-Bridges e de aristapédia.

Ovos e larvas de aristapédia-Bridges foram submetidos à baixa temperatura de $14,4^{\circ} \mathrm{C}$ por um periodo de 1 a 8 dias. Os resultados mostraram que a temperatura énsaiada acentua a expressão do caráter, fazendo o órgão anţ̣̂nal evoluir cada vez mais na direção do tarso, e que os maiores efeitos, para qualquer espaço de tempo, foram obtidos quando o tratamento foi iniciado a partir do $4 .^{\circ}$ dia do desenvolvimento do óvo. O tratamento depois que o óvo foi posto ou 6 dias após, produz aproximadamente os mesmos resultados, quàlquer que seja a du ração. Um tratamento iniciado 1 ou 2 dias depois da postura produz pequeno efeito se for suspenso depois do 5.0 dia; se continuado através dêsse dia, dá ưm resültado proporcional à duração, o mesmo acontecendo com o tratamento iniciado no $3 .^{\circ}$ ou no $4 .^{\circ}$ dia. Nos casos extremos o órgão afetado se apresentava com a morfologia que exibe em aristapédia, isto é, inteiramente semelhante a tarso. A ação da temperatura se faz igualmente sentir nas patas, reduzindo o número de artículos tarsais ou mesmo suprimindo inteiramente os tarsos.

Com o emprêgo de temperaturas elevadas $\left(29^{\circ} \mathrm{C}\right.$ por alguns dias ou $35^{\circ} \mathrm{C}$ por um periodo de 12 a 24 horas) obteve VILLEE um resultado inteiramente oposto ao precedente, ou seja, a transformação do órgão antenal de aristapédia-Bridges numa estrutura mais próxima de arista que de tarso. Porém, tঞmbém aqui, o efeito da temperatura-se fez sentir mais intensamente qando o tratamento foi realizado no $3 .^{\circ}$ ou $4 .^{\circ}$ dia 
após a postura do ôvo. Antes ou depois dêsse periodo, os resultados foram pequenos ou nulos.

Com relação à aristapédia as experiências de VILLEE demonstraram que a temperatura de $14,4^{\circ} \mathrm{C}$ atuando nas mesmas condições da experiência anterior, não produz efeito algum, quer acentuando, quer diminuindo a expressão do caráter. Porém, a temperatura de $29^{\circ} \mathrm{C}$ começando no $2 .^{\circ}, 3^{\circ}, 4^{\circ}$ ou $5 .^{\circ}$ dia depois da postura, produz uma estrutura mista, cuja metade proximal se assemelha a tarso e a metade distal a arista.

Cruzando aristapédia-Bridges com "aristaless" constatou VILLEE que 0 gen introduzido reagia reduzindo a parte aristal do órgão antenal. Os F2 submetidos a baixa temperatura em diversos periodos do desenvolvimento e por um lapso variável de tempo, mostraram, que tódas as vezes que o tratamento se fazia sentir dando ao orgão antenal uma estrutura tarsal, êste deixava de reagir, embora o gen continuasse em atividade e se manifestasse, como de ordinário, sôbre as cerdas escutelares posteriores.

Em resumo, as experiências de VILLEE mostraram que a expressão de aristapédia-Bridges acentua-se pela ação de baixa temperatura e diminui pela ação de temperatura elevada, sendo que em qualquer caso os melhores efeitos são conseguidos quando o tratamento se inicia depois do $4 .^{\circ}$ dia do desenvolvimento do ôvo.

VILLEE faz sentir que a temperatura atua modificando a velocidade do desenvolvimento e que a ação do frio em aristapédia-Bridges revelou uma diferença quantitativa entre os diversos alelos. Assim, a baixa temperatura, diminuindo a velocidade do desenvolvimento, permite ao gen aristapédia-Bridges, trabalhando mais lentamente, porém por mais longo tempo produzir um fenotipo semelhante àquele que produz o gen aristapédia, à temperatura normal, trabalhando mais rápidamente por um tempo mais curto. Aliás, uma dieta adequada, diminuindo a velocidade do desenvolvimento, conduz ao mesmo resultado.

Segundo VILLEE os diferentes alelos tanto podem atuar pł:la produção de alguma "substância de tarso" conforme sugere WADDINGTON, ou afetar o tempo de maturação dos discos antenais, como pretende GOLDSCHMIDT.

Entretanto, os resultados experimentais de VILLEE estão em desacôrdo com as hipoteses de GOLDSCHMIDT e de WADDINGTON, conforme êle proprio faz notar. Assim, de conformidade com o primeiro dêsses autores, o gen aristapédia atua nas larvas de menos de 2 1/2 dias de idade, acelerando a ma- 
turação dos discos antenais, para que êles possam sofrer, conjuntamente com os discos podais que nessa ocasiáo amadureẹm, a ação das substáncias determinadoras de patas. De conformidade com o segundo, a bifurcação que conduz o desenvolvimento para o lado da arista ou do tarso deve processar-se muito prematuramente no estado larval. Porém, a influência da temperatura se mostra muito mais acentuada num momento que corresponde aproximadamente ao inicio da segmentação dos discos antenais, que nessa ocasião já deveriam estar determinados como patas (GOLDSCHMIDT) ou se encaminhando por uma das vias do desenvolvimento (WADDINGTON).

VILLEE acha que a bifurcação do sistema de WADDINGTON ou se dá mais tarde do que se supunha, ou então, se de fato se verificar muito cedo, a via seguida pelo desenvolvimento poderá mais uma vez ser mudada. Na minha opinião, nenhuma dessas possibilidades corresponde aos fatos observados. Mais tarde do que sup̃̄e WADDINGTON a bifurcação não se dá, porquanto ficou bem demonstrado pelas experiencias de transplantação de $B R A U N$, que desde os $21 / 2$ dias de idade já os discos se apresentam definitivamente determinados, o que significa que já se encaminharam por uma das vias que ronduzem à diferenciação final. A segunda possibilidade só se daria se pudéssemos aceitar a teoria de GOLDSCHMIDT mocificada por VILLEE, isto é, admitindo que uma parte do disco antenal amadurece primeiro, recebendo uma determinação, encuanto que a parte restante, amadurecendo mais tarde, receberia a outra determinação. Nesse caso, os efeitos extremos da baixa temperatura, produzindo uma estrutura inteiramente tarsal, poderiam ser interpretadas como exercendo uma ação inibidora que impedisse a segunda bifurcação. Mas o própric VILLEE reconhece que a explicação proposta por GOLDSCHMIDT não encontra apóio nos fatos. São daquele autor as seguintes palavras:

"The results of these experiments are not readily explained by Goldschmidt's theory of the action of homoetic loci. If the only action of aristapedia is the hastering of the maturation of the antennal disc so that it may be acted upon by the leg evocator at 21/2 days instead of by the antennal evocator at 4 to $41 / 2$ days, then heat treatment.s which are begun after 4 days of development have been passed at normal temperature, should have no effect on development. The antennal disc should have been "evoked" by the leg evocator and be well on its way in the dire- 
ction of leg development. However, heat treatements begun at this time will shift the development of a certain percentage of antennal appendages so that more or less of the distal portion of the antenna becomes arista-like; the appendeges are shifted from type VIII (the normal aristapedia phenotype) to as low as type IV, in which the distal half of the appendage is arista-like and the proximal half tarsus-like.

In the development of aristapedia-Bridges, at normal temperature, according to the Goldschmidt theory, only a small part of the antennal disc has become mature (due to the action of the ssaB gene) at the time the leg evocator diffuses in, and therefore, only a small part of the antenna becomes leg-like. There would be no way of explaining on this basis alone how cold treatments begur a day or two after this is supposed to have occurred could cause a further shift towards leg development, not only of the al ista but of the rest of the antenna.

Whether some modification of the Goldschmidt thecry or some completely new theory of the action of homoeotic loci in development is necessary cannot be decided from the present data." (1943, p. 96).

Ora, se a teoria de GOLDSCHMIDT não corresponde aos fatos, ela não serve de base à introdução de mais uma ramifícação no sistema de WADDINGTON, nem mesmo admitincio-se a hipótese da maturação diferencial dos discos antenais apresentada por VILLEE. Aliás, não se conhece da história dos oiscos imaginais momento algum em que êles possam ser considerados como indiferentes, de sorte que qualquer teoria baseada na maturação de esbôços embrionários ao tempo em que evocadores diferentes entram em ação, estará em desacôrdo com os fatos.

VILLEE (1944) estudou ùltimamente a ação da temperatura sôbre o mutante proboscipédia, chegando a resultados da mesma natureza, porém opostos aos obtidos com aristapédia.

Trata-se aqui de uma mutação do III cromossômio, que transforma os palpos labiais numa estrutura que ora se assemelha a tarso, ora a arista, havendo casos em qua os apêndices s.presentam na base caracteristicas tarsais e na extremidade caracteristicas aristais.

Os resultados obtidos podem ser resumidos da seguinte maneira : 
1) O frio $\left(15^{\circ} \mathrm{C}\right)$ aplicado às larvas de proboscipédia orienta o desenvolvimento para o lado da antena, de maneira que sòmente se formam apêndices semelhantes a arista. A modificação é proporcional à duração do tratamento, mostrando-se mais pronunciada quando o tratamento se inicia 5 dias após a postura do ôvo.

2) O calor $\left(29^{\circ} \mathrm{C}\right)$ produz um efeito contrário, levando o desenvolvimento à formação de apêndices semelhantes a tarsos. Igualmente aqui os resultados se mostram proporcionais a duração do tratamento, os melhores efeitos aparecendo quando as aplicações começam 4 ou 5 dias depois da postura.

Estes resultados, conjuntamente com os precedentemente obtidos, levaram VILLEE à conclusão de que os gens aristapédia e proboscipédia não afetam o sistema de evocadores unas sim o tempo que levam os discos imaginais para alcançar competência, isto é, para se porem em estado de poder reagir à ação dos evocadores.

A idéia de VILLEE, em suas próprias palavras, é a seguinte :

"Since it is known that in the normal fly the leg discs begin to segment 2 days before the antennal discs, it is reasonable to suppose that the tarsus evocator is given off before the arista evocator. If we now suppose that in the normal fly each disc matures at the proper time to be aifected by the proper evocator, we may call this rate of maturation unity. It would differ in its absolute value for the different discs, of course. If we now suppose that aristapedia gene alters the rate of development of the antennal discs so that it is less than 1 (lesse than normal), and that proboscipedia gene alters the rate of development of the labial buds so that it is greater than 1 (more than normal) the results of temperature would follow. (Pag. 99).

Transcrevi literalmente a hipótese de VILLEE para mostrar que ela em nada difere da de GOLDSCHMIDT, estando como esta em franco desacórdo com os fatos e sujeita às mesmas críticas precedentemente feitas. A hipótese não explica o motivo pelo qual o esbóço dos palpos sob o mesmissimo contròle gênico, ora adquire competéncia conjuntamente com os discos podais, determinando-se como tarsos, ora conjuntamente com os discos antenais e por conseguinte muito mais tardiamente, determinando-se como aristas, ora, enfim, tornando-se em parte competente ao mesmo tempo que os discos 
de patas e em parte conjuntamente com os discos de antenas, para formar uma estrutura mista, assemelhando-se na base a tarso e na extremidade a arista.

O que os dados de VILLEE parecem mostrar, de conformidade com os fatos já adquiridos, é que o esbôço labial de proboscipédia não se formou, sendo desde o início substituido por um esbóço constitucionalmente duplo, parte tarsal, parte arì;tal, que se desenvolve mais para um lado ou mais para outro, cie acôrdo com as circunstâncias. Uma dada temperatura pode favorecer o desenvolvimento da parte tarsal, inibindo mais ou menos compleamente $o$ desenvolvimento da parte aristal. Jma outra temperatura poderia dificultar 0 desenvolvimento da parte tarsal, que apenas se iniciaria, ativando, pelo contrário, o desenvolvimento da parte aristal, que logo a seguir entraria a se constituir.

Torna-se pois necessário descobrir um meio de explicar o mecanismo da determinação dos esboços embrionários, bem como a maneira pela qual um disco imaginal possa substituir um outro ou se constituir em disco misto, com duas potencialidades especificamente distintas, quantitativamente equivalentes ou diferentes.

Foi o que fez PIZA (1941) postulando a determinação dcs discos imaginais pelas substâncias órgano-formativas do citoplasma das células, substâncias estas, provenientes do blastema do ôvo.

Está amplamente demonstrado por inúmeras experiências cie vários autores, que o blastema periférico do ôvo dos Dípteros e de outros insetos, contém substâncias responsáveis pelo desenvolvimento de determinados órgãos ou partes do corpo, nêles dispostas numa ordem definida. (V. PIZA 1941).

Quando se constitui a blastoderme, cada célula deve conter em seu citoplasma a substância encontrada na região compreendida pelos planos que lhe deram origem. E assim a hipoderme da larva deve possuir regiões diferindo entre si pela qualidade do citoplasma de suas células. $\mathbf{E}$ visto que os discos imaginais resultam da proliferação de células hipodermais, é justo pensar-se que cada disco tenha, constitucionalmente, o mesmo valor das células de que proveio. Assim, admitindo que no blastema já existam substâncias formadoras de ôllho, de antera, de pata, de asa, etc. e que essas substancias passem para \&:s células que mais tarde, multiplicando-se, originam os discos 
imaginais respectivos, teriamos ai um mecanismo de determinaçáo em perfeito acórdo com os fatos.

Os discos desde que se constituem estarão já determinados pela natureza do citoplasma de suas células. Um disco antenal só produzirá uma pata se ele contiver substáncia de pata em lugar de substância de antena. Mas nesse caso êle não deve ser considerado como disco antenal e sim como um disco podal que se constituiu numa região diferente daquela em que habitualmente aparece. De outro lado, se um dado disco tanto pode se desenvolver em antena como em pata, ou numa estrutura mista, em parte antenal, em parte podal, a conclusão que se impõe ê que êsse disco reja constituido de células contendo ambas as substâncias, sendo que, conforme as circunstâncias, uma ou outra toma a primazia na orientação do órgão.

Se atribuirmos aos gens (funções cromossômicas) a facul.. dade de alterar a distribuiçăo normal das difel'entes substâncias organo-formativas do blastema, transpondo material de patas para a área antenal, discos mistos podem se constituir contendo dois tipos de células ou células de um só tipo com a citoplasma provido das duas substáncias. E assim os fatores que influenciam o desenvolvimento, atuando sóbre essas subs1âncias, poderiam orientar o esbóço embrionário para ilın ou jara outro lado.

Entretanto, de acórdo com a opinião defendida em outro trabalho (PIZA 1941), o citoplasma toma a iniciativa em todos os processos de desenvolvimento, arrancando, no momento oportuno, da parte dos cromossómios, uma reaçã) especifica e proporcional. Assim, as modificaçōes operadas nas substàncias órgano-formativas do blastema ou a transposição dessas substancias podem originar-se direta e indiretamente do citophasma como verdadeiras mutações citoplasmáticas, ncompanhadas de mutações cromossômicas que alteram mais ou menos profundamente a reatividade désses elementos do núcleo O comportamento da homeose segundo as leis mendelianas seria então devido à participaçáo dos cromossómios no fenómeno, co passo que a expressão do caráter seria principalmente devida à proporção relativa das diferentes substancias presentes no disco. Os fenómenos homeóticos que se não comportarem de conformidade com as leis de Mendel, podem ser interpretados como devidos a mutaçóes citoplasmáticas não acompanhadas de mutações cromossômicas.

A grande variabilidade na expressão dos caracteres homeóticos, que vai das formas mais extremas até aos individucs 
que apesar de homozigotes, em nada diferem dos individuos rormais, e bem assim a assimetria com que o fenómeno se manifesta, apoiam a interpretação baseada na proporção relativa das substâncias responsáveis pela determinação, contidais nos discos.

Da conformidade com essa concepção, a homeose não prova a homologia dos apêndices dos Insetos (VILLEE, 1942) porquanto a substituição de substâncias nos discos imaginais poder:i fazer nascerem patas em lugar de asas, como aliás já ioi observado, se bem que sem confirmação (BATESON 1894, p.148), sem que êsses órgãos possam ser considerados como homólogos, na assepção usual do têrmo.

\section{SUMMARY}

A preliminary account on the normal development of the imaginal discs in holometabolic Insects is made to serve as an introduction to the study of the hereditary homoeosis. Several iacts and experimental data furnished specially by the students of Drosophila are brought here in searching for a more adequate explanation of this highly interesting phenome110n. The results obtained from the investigations of different homoeotic mutants are analysed in order to test Goldschmidt's theory of homoeosis. Critical examination of the basis on which this theory was elaborated are equally made. As a result from an extensive theoretical consideration of the matter and a long discussion of the most recent papers on this subject the present writer concludes that the Goldschmidt explanation of the homoeotic phenomena based on the action of diffusing substances produced by the genes, the "evocators", and on the alteration nf the normal speed of maturation of the imaginal discs equally due to the activity of the genes, could not be proved and therefore should be abandoned. In the same situation is any other explanation like that of Waddington or Villee considered as fundamentally identical to that of Goldschmidt.

In order to clear the problem of homoeosis in terms which seem to put the phenomenon in complete agreement with the known facts the present writer elaborated a theory first published. a few years ago (1941) based entirely on the assumption that the imaginal discs are specifically deter.alned by some kind of substances, probably of chemical nature, contained in the cytoplam of the cells entering in the consti- 
tution of each individual disc. These substances already present in the blastem of the egg in which they are distributed in a definite order, pass to different cells at the time the blastem is transformed into blastoderm. These substances according to their organogenic potentiality may be called antenal-substance, legsubstance, wing-substance, eye-substance, etc. The hipoderm of the embryo resulting from the multiplication of the blastoderm cells would be constituted by a series of cellular areas differing from each other in their particular organoformative capacity. Thus the hypoderm giving rise to the imaginal discs, it follows that each disc must have the same organogenic power of the hypodermal area it came from. Therefore the discs cre determinated since their origin by substances enclosed in the cytoplasm of their cells and consequently can no longer alter their potentiality.

When an antennal disc develops into a leg one can conclude that this disc in spite of its position in the body of the larva is not, properly speaking, an antennal disc but a true leg disc whose cells instead of having in their cytoplasm the antennal substance derived from the egg blastem have in its place the leg-substance. Now, if a disc produces a tarsus or an antenna or even a compound appendage partly tarsus-like, partly antenna-like, it follows that both tarsal and antennal substances are present in it. The ultimate aspect of the compound structure depends upon the reaction of each kind of substance to the different causes influencing development. For instance, temperature may orient the direction of development either wowards arista or tarsus, stimulating, or opposing to the one or the other of these substances.

Confering to the genes the faculty of altering the constitution of the substances containing in the cytoplasm forming the egg blastem or causing transposition of these substances from one area to another or promoting the substitution of a given substance by a different one, the hereditary homoeosis may be easily explained. However, in the opinion of the present writer cytoplasm takes the initiative in all deveiopmental process, provoking the chromosomes to react specilically and proportionally. Accordingly, the mutations causing homoeotic phenomena may arise independently at different time in the cytoplasm and in the chromosomes. To the part taken by the chromosomes in the manifestation of the homoeotic characters is due the mendalian ratio observed in homoeotic X normal crosses. Expression, in itself, is mainly due to the proportion of the different substances in the cells of the 
affected discs. Homoeotic phenomena not presenting mendelian ratio may appear as consequence of cytoplasmic mutation not accompanied by chromosomal mutation.

The great variability in the morphology of the homoeotic characteres, some individual being changed towards an extreme expression of the mutant phenotype while others in spite of their homozigous constitution cannot be distinguished from the normal ones, strongly supports the interpretation based on the relative proportion of the determining substances in the discs. To the same interpretation point also asymetry and other particularities observed in the exteriorization of the phenomenon.

In conformity with this new conception homoeosis should not prove homology of Insect appendages (Villee 1942) since a mere replacement of substances may cause legs to develop in substitution of the wings, as it was already observed (requiring confirmation in the opinion of Bateson 1894, p. 184) and no one would conclude for the homology of these organs in the usual meaning of the term.

\section{LITERATURA CITADA}

BALKASHINA, E. I. 1929 - Ein Fall der Erbhomöosis (die Genovariation "Aristapedia") der Drosophila melanogaster Arch. Entwm. 115: 448-463.

BATESON, W. 1894 - Materials for the study of variation. Macmillan and Co. London and New York. XV-598 p. $395 \mathrm{f}$.

BODENSTEIN, D. 1941 - Investigations on the problem of metamorphosis. VIII - Studies on leg determination in insects. Jour. Exp. Zool. 87: 31-53.

BRAUN, W. 1940 - Experimental evidence on the production of the mutant "Aristapedia" by a change of developmental velocities. Genetics 25: 143-149.

CHEN, T-Y. 1929 - On the development of imaginal buds in normal and mutant Drosophila melanogaster. Jour. Morph. Physiol. 47: 136-187.

CUENOT, L. 1921 - Régéneration de pattes à la place d'antennes sectionées chez un Phasme. Comp. Rend. Ac. Sc. Paris. 172: 949-952.

DAWYDOFF, C. 1928 - Traité d'embryologie comparée des invertebrés. Masson \& Cie. Paris, XIV-930 p. 509 f.

GEIGY, R. 1931 - Erzeugung rein imaginaler Defekte durch ul- 
traviolette Eibestrahlung bei Drosophila melanogaster. Roux's Arch. f. Entwm. d. Org. 125: 406-447.

GOLDSCHMIDT, R. 1927 - Physiologische Theorie der Vererbung. Julius Springer, Berlin, VI-247 p. $59 \mathrm{f}$.

GOLDSCHMIDT, R. 1938 - Physiological genetics. Mc Graw Hilk Book Comp. Inc. New York and London. IX-375 p. $54 \mathrm{f}$.

GOLDSCHMIDT, R. 1940 - The material basis of evolution. Yale Un. Press. XI-436 p. 83 f.

HERBST, C. 1896 - tber Regeneration von antennähnlichen Organen an Stelle von Augen. Arch. f. Entwm. 2: 554-558.

KORSCHELT, E. 1927 - Regeneration und Transplantation. I. Band. Borntraeger, Berlin. XII-818 p. $395 \mathrm{f}$.

XORSCHELT, E. 1936 - Vergleichende Entwicklungsgeschichte der Tiere. Gustav Fischer, Jena. XX-1314 p. 560 f.

PIZA, S. de TOLEDO. 1941 - O citoplasma e o núcleo no desenvolvimento e na Hereditariedade. Piracicaba. 146 p. $26 \mathrm{f}$.

PRZIBRAM, H. 1909 - Experimental Zoologie. 2. Regeneration. Franz Deuticke, Leipzig u. Wien. VIII-338 p. 16 est.

STRASBURGER, E. H. 1935 - Drosophila melanogaster Meig. Eine Einführung in den Bau und Entwicklung. Julius Springer, Berlin. 60 p. $71 \mathrm{f}$.

VILLEE, C. A. 1942 - The phenomenon of homoeosis. Am. Nat. 76: $494-506$.

VILLEE, C. A. 1942a - A study of hereditary homoeosis: the mutant tetraltera in Drosophila melanogaster. Univ. Calif.

Publ. Zool. 49: 125-184.

VILLEE, C. A. 1943 - Phenogenetic studies of the homoeotic mutants of Drosophila melanogaster. I. The effects of temperature on the expression of aristapedia. Jour. Exp. Zool. 93: 75-98.

VILLEE, C. A. 1944 - Phenogenetic studies of homoeotic mutants of Drosophila melanogaster. II. The effects of temperature on the expression of proboscipedia. Jour. Exp. Zool. 96: 85-102.

WADDINGTON, C. H. 1940 - Organizers \& genes. Cambridge. $\mathrm{X}-160$ p. $15 \mathrm{f}$. 